\title{
Characteristics of cross-hybridization and cross-alignment of expression in pseudo-xenograft samples by RNA-Seq and microarrays
}

\author{
Camilo Valdes ${ }^{1}$, Pearl Seo ${ }^{2}$, Nicholas Tsinoremas ${ }^{1,4}$ and Jennifer Clarke ${ }^{1,2,3^{*}}$
}

\begin{abstract}
Background: Exploring stromal changes associated with tumor growth and development is a growing area of oncologic research. In order to study molecular changes in the stroma it is recommended to separate tumor tissue from stromal tissue. This is relevant to xenograft models where tumors can be small and difficult to separate from host tissue. We introduce a novel definition of cross-alignment/cross-hybridization to compare qualitatively the ability of high-throughput mRNA sequencing, RNA-Seq, and microarrays to detect tumor and stromal expression from mixed 'pseudo-xenograft' samples vis-à-vis genes and pathways in cross-alignment (RNA-Seq) and cross-hybridization (microarrays). Samples consisted of normal mouse lung and human breast cancer cells; these were combined in fixed proportions to create a titration series of $25 \%$ steps. Our definition identifies genes in a given species (human or mouse) with undetectable expression in same-species RNA but detectable expression in cross-species RNA. We demonstrate the comparative value of this method and discuss its potential contribution in cancer research.
\end{abstract}

Results: Our method can identify genes from either species that demonstrate cross-hybridization and/or cross-alignment properties. Surprisingly, the set of genes identified using a simpler and more common approach (using a 'pure' cross-species sample and calling all detected genes as 'crossers') is not a superset of the genes identified using our technique. The observed levels of cross-hybridization are relatively low: $5.3 \%$ of human genes detected in mouse, and $3.5 \%$ of mouse genes detected in human. Observed levels of cross-alignment are practically comparable to the levels of cross-hybridization: $6.5 \%$ of human genes detected in mouse, and $2.3 \%$ of mouse genes detected in human. We also observed a relatively high percentage of orthologs: $40.3 \%$ of cross-hybridizing genes, and $32.2 \%$ of cross-aligning genes.

Normalizing the gene catalog to use Consensus Coding Sequence (CCDS) IDs (Genome Res 19:1316-1323, 2009), our results show that the observed levels of cross-hybridization are low: $2.7 \%$ of human CCDS IDs are detected in mouse, and 2.4\% of mouse CCDS IDs are detected in human. Levels of cross-alignment using the RNA-Seq data are comparable for the mouse, 2.2\% of mouse CCDS IDs detected in human, and 9.9\% of human CCDS IDs detected in mouse. However, the lists of cross-aligning/cross-hybridizing genes contain many that are of specific interest to oncologic researchers.

(Continued on next page)

\footnotetext{
* Correspondence: JClarke@biostat.med.miami.edu

${ }^{1}$ Center for Computational Science, University of Miami, Miami, FL, USA

${ }^{2}$ Department of Medicine, University of Miami, Miami, FL, USA

Full list of author information is available at the end of the article
} 
(Continued from previous page)

Conclusions: The conservative definition that we propose identifies genes in mouse whose expression can be attributed to human RNA, and vice versa, as well as revealing genes with cross-alignment/cross-hybridization properties which could not be identified using a simpler but more established approach. The overall percentage of genes affected by cross-hybridization/cross-alignment is small, but includes genes that are of interest to oncologic researchers. Which platform to use with mixed xenograft samples, microarrays or RNA-Seq, appears to be primarily a question of cost and whether the detection and measurement of expression of specific genes of interest are likely to be affected by cross-hybridization or cross-alignment.

Keywords: Microarray, RNA-Seq, Cross-hybridization, Cross-alignment, Tumor microenvironment, Xenograft, Pathway analysis

\section{Background}

It is well understood by oncologists that tumor growth and metastasis depend on changes in the tumor microenvironment or stroma. Stromal changes have been the focus of numerous research publications and have led to insights in both tumor development and promising new avenues for treatment [1-7].

In order to study molecular changes in stroma from tissue samples, it is necessary to separate tumor tissue from stromal tissue. Without this separation we have sample heterogeneity, which is well known to severely limit the conclusions that can be made about the specificity of molecular changes and their biological causes [5,7-11]. This separation can be difficult in contexts where tumors are small or not well differentiated. For example, in mouse tumor xenograft models, human cancer cells are grown in immune-suppressed mice [12-15]. These models are popular in oncologic research for studying mechanisms of tumor growth and metastasis, as well as drug response. In such studies, secondary tumors (at sites of metastasis) are often quite small and difficult to separate surgically from the surrounding stroma. Hence, mouse xenograft samples consist of a mixture of human tumor and mouse stromal tissues, and the task of separating tumor tissue from stromal tissue is a critical one.

Historically, the tumor-stromal separation step has been solved in two different ways: either by laser capture microdissection (LCM; $[14,16,17])$ of the tissue samples or in silico dissection of data from undissected samples $[17,18]$. LCM is very time consuming, and specialized equipment is required to obtain a sufficient quantity of biological material for profiling. If the sample is in suspension, cell-sorting methods can be used to isolate specific cells, although this requires a suitable biomarker for the cell type(s) of interest. The main drawback of cell-sorting with respect to molecular profiling is that the act of separation itself can alter the expression of molecular markers $[10,19,20]$. In silico dissection can be used successfully to assign expression levels to different tissues; however, these methods may have difficulty with cross-hybridization of human chip probes with homologous mouse genes - and vice versa [21-23].
A potential solution is the use of high-throughput RNA sequencing (RNA-Seq) data to measure expression. RNASeq is a relatively new, but very promising method used to detect and measure the abundance of RNAs [2,4,24] using modern DNA sequencing technologies [1,2,4,6,25]. RNASeq does not depend on genome annotation for prior probe selection and avoids biases introduced during hybridization of microarrays $[8,26]$. However, RNA-Seq does depend on alignment of reads to a reference sequence [12,14,24], and current wet-lab RNA-Seq protocols and strategies require lengthy library preparation procedures.

An alternate method for identifying cross-hybridization/ cross-alignment would be to profile 'pure' human and mouse samples using both mouse and human platforms. Genes detected when examining pure human tissue with a mouse platform, and vice versa, are defined as crosshybridizers/cross-aligners. This method should identify genes whose expression fluctuates from undetectable to detectable or change their detectable levels when going from a same-species to a cross-species platform. Interestingly, we found that by using a more conservative definition, but a more complex approach - using a titration series to identify genes whose expression shifts from undetectable to detectable - we identified genes that could not be identified using only 'pure' species samples.

We report on a qualitative comparison of the abilities of RNA-Seq and microarray data to determine tumor (human) and stromal (mouse) expression from mixed samples in terms of cross-alignment (RNA-Seq) and cross-hybridization (microarrays). We use titration data from experiments designed to create pseudo-xenograft samples, in triplicate, involving total RNA from mouse and human combined in different proportions and analyzed by both microarrays and RNA-Seq.

\section{Methods}

\section{RNA sources}

Samples consisted of normal mouse lung and human breast cancer cells (the human samples consisted entirely on pre-established human cell lines, and did not include 


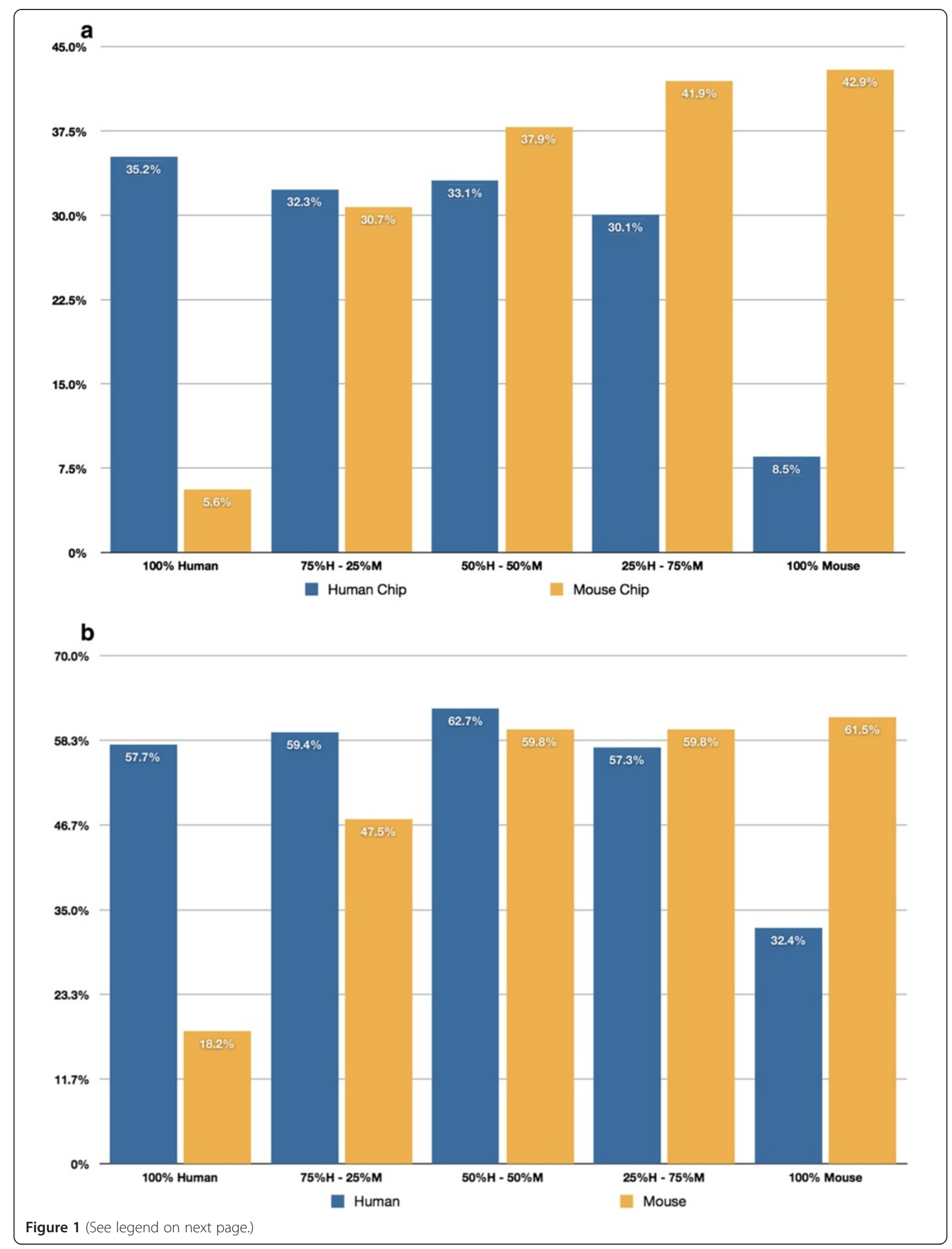


any human subjects); these were combined in fixed proportions to create a titration series of $25 \%$ steps. The titration data assembles a series of "pseudo-xenograft" samples containing both human and mouse components. MDAMB-231 human breast carcinoma cell line was obtained from the American Type Culture Collection, and maintained according to the supplier's instructions. RNA was isolated from three independent cultures of subconfluent MDA-MB-231 cells in the exponential phase of growth. NOD/SCID gamma mice were obtained from The Jackson Laboratory, and normal lung tissue was harvested from three independent age-matched mice. All animals were maintained in accordance with the guidelines of the Institutional Animal Care and Use Committee at the University of Miami.

RNA was extracted from cultured MDA-MB-231 cells and normal lung tissue using Trizol Reagent (Invitrogen) according to the manufacturer's instructions. Concentration and yield of RNA samples were determined using a NanoDrop ND-1000 Spectrophotometer (NanoDrop Technologies). RNA integrity was determined by analysis on an Agilent 2100 Bioanalyzer (Agilent Technologies) following the manufacturer's recommendations. Only samples with a RIN score greater than 7.0 were used for the subsequent molecular analysis.

\section{Microarrays}

Samples were prepared according to the manufacturer's instructions, and analyzed using HumanWG-6_V3_0_R1 and MouseWG-6_V2_0_R0 Expression BeadChips (illumina, Inc.). Samples consisted of total RNA combined in the following proportions (human/mouse): 100/0, 75/25, $50 / 50,25 / 75$, and $0 / 100$. Raw expression data was background corrected, quantile normalized, and $\log 2$ transformed using the GeneSpring GX software. Probesets with detection p-values less than 0.05 in two of three independent replicates were considered as "present" and included in further analysis.

\section{RNA-Seq}

mRNA (200 ng) was fragmented at $70 \mathrm{uC}$ for 5 minutes in a fragmentation buffer (Ambion), and converted to firststrand cDNA using Superscript III (Invitrogen); followed by second-strand cDNA synthesis using Escherichia coli DNA pol I (Invitrogen). The double stranded cDNA library was further processed by Illumina Genomic DNA Sample Prep
Kit. It involved end repair using T4 DNA polymerase, Klenow DNA polymerase, a T4 Polynucleotide kinase followed by a single "A" base addition using Klenow 39 to 59 exo2 polymerase, and was ligated with Illumina's adaptor oligo mix using T4 DNA ligase. The adaptor-ligated library was size-selected by separating on a $4 \%$ agarose gel and cutting out the library smear at 200-base-pairs (bp) (625 bp). The library was PCR-amplified by Phu polymerase (Stratagene) and purified by Qiaquick PCR Purification Kit (Qiagen). The library was quantified with Quant-iT Picogreen dsDNA Assay Kit (Invitrogen) on a Modulus Single Tube Luminometer (Turner Biosystems) following the manufacturer's instructions. The resulting library (10 $\mathrm{nM}$ ) was used to prepare flowcells with approximately 30,000 clusters per lane. Sequencing of all libraries was performed on an Illumina Genome Analyzer IIx yielding 82,447,146 single-end 36-base reads using CASAVA (v.1.3).

The resulting reads were mapped using the TopHat $[14,27]$ spliced-read mapper to the human genome (hg19) and the mouse genome (mm9) obtained from the University of California, Santa Cruz (UCSC) Genome Browser [18,28]. Additionally, the Ensembl [10,13] human and mouse transcriptomes were also supplied to TopHat. Proteincoding genes with at least 5 uniquely aligned reads $[16,21]$ within their respective gene region were considered as being "present" [2,4,19]. We also experimented with aligning using the BWA aligner [25] - to the transcriptome sequences directly as opposed to the entire genomic reference (Additional file 1: Figures S6 and S7) to gauge any potential advantages or changes in alignment patterns. However we found no perceived benefit as the transcriptome alignment patterns followed the genomic ones, albeit at lower levels.

\section{CCDS data}

Consensus Coding Sequence (CCDS) [29] annotation data was obtained from the CCDS project FTP repository at NCBI. CCDS data was used to normalize the gene catalog in both the microarray and RNA-Seq analyses. For human, 25,504 CCDS IDs were employed; for mouse, 22,131 CCDS IDs were employed in the analysis. The human microarray chip contained 48,811 probes; of these we were able to summarize 21,636 CCDS IDs, of which 16,579 are unique ids. The mouse microarray chip contained 45,282 probes; we summarized them into 20,209 mouse CCDS IDs, of which 13,518 are unique. In review, the human microarray chip contained only $65.0 \%$ of current human 


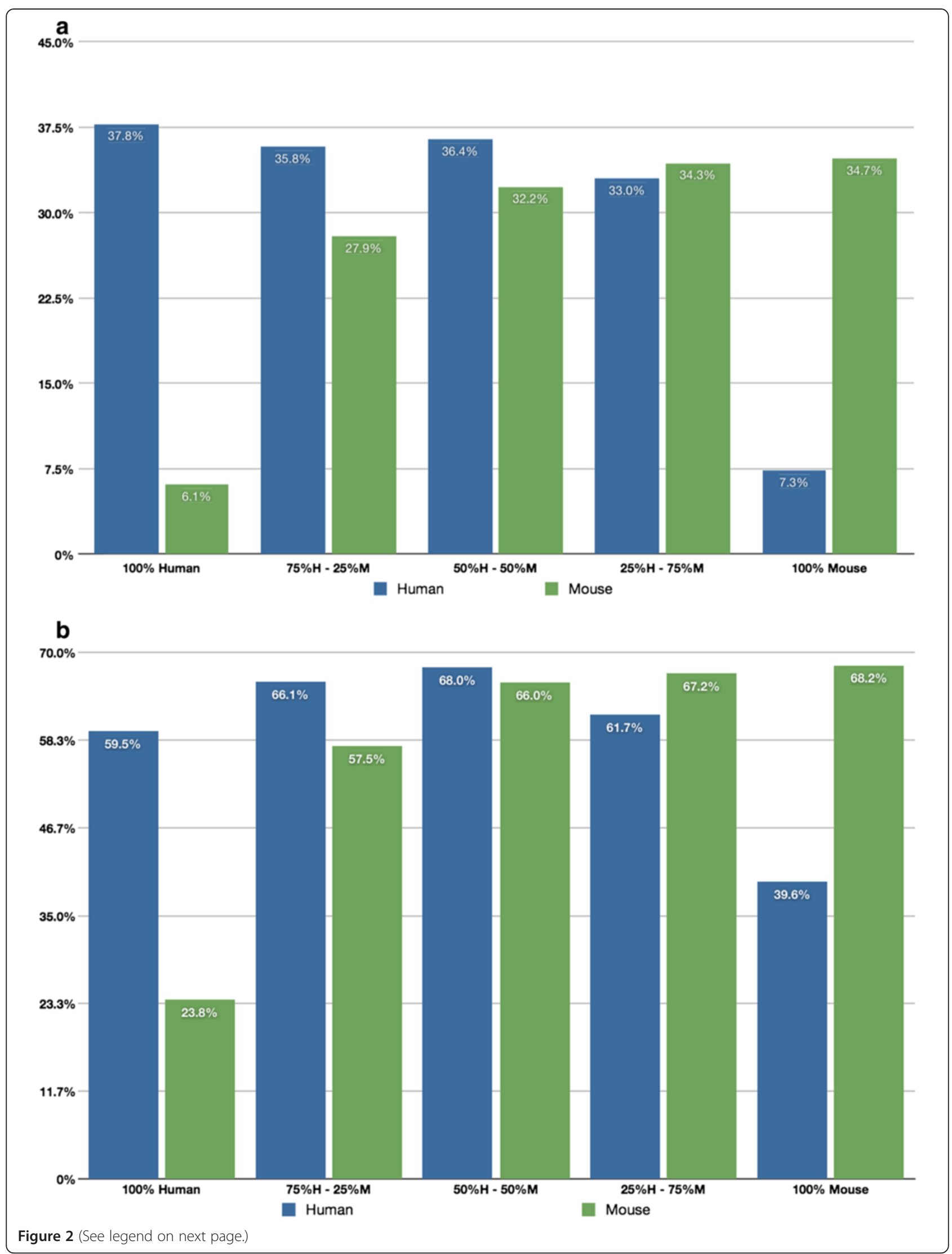


(See figure on previous page.)

Figure 2 Human and mouse CCDS Ids detected by microarrays. a. Human and mouse CCDS IDs detected by microarrays. Percentage of CCDS IDs within each sample type detected by the microarray chips. Blue bars represent the percentage of human CCDS IDs that are detected in the human microarray chip; green bars represent the percentage of mouse CCDS IDs detected in the mouse microarray chip. $\mathbf{b}$. Human and mouse CCDS IDs detected by RNA-Seq. Percentage of CCDS IDs detected within each sample type by RNA-Seq. Blue bars represent the percentage of human CCDS IDs detected by aligning to the human reference; green bars represent the percentage of mouse CCDS IDs detected by aligning to the mouse reference.

CCDS IDs; the mouse microarray chip contained only $61.1 \%$ of current mouse CCDS IDs.

\section{Cross-hybridization \& cross-alignment}

We define a gene which cross-hybridizes (or cross-aligns) from mouse to human (a mouse crosshyb, or mouse cross-aligner) as one which exists in the set defined by $((B \cup C \cup D)-A)$; where "A", "B", "C", and " $D$ " are defined as follows: "A" is the set of all genes detected when the pure mouse RNA sample was hybridized onto mouse chips (or aligned to the mouse genome); "B" is the set of all genes detected when the $25 \%$ human \& $75 \%$ mouse RNA samples were hybridized onto mouse chips (or aligned to the mouse genome); " $\mathrm{C}$ " is the set of all genes detected when the $50 \%$ human \& 50\% mouse RNA samples were hybridized onto mouse chips (or aligned to the mouse genome); and finally, " $\mathrm{D}$ " is the set of all genes detected when the $75 \%$ human \& $25 \%$ mouse RNA samples were hybridized onto mouse chips (or aligned to the mouse genome). Accordingly, a gene that cross-hybridizes (or cross-aligns) from human to mouse (a human crosshyb, or human cross-aligner) is defined analogously.

\section{Results}

\section{Intraspecies and interspecies detection}

Figure $1 \mathrm{a}$ and $\mathrm{b}$ show the percentages of human and mouse genes detected by microarray and by RNA-Seq in each triplicate of samples using a disjoint gene catalog, i.e., the gene list used in the microarray analysis is the entire gene inventory on the chip, and the gene list used in the RNA-Seq analysis is the complete Ensembl protein-coding gene catalog. Figure $2 \mathrm{a}$ and $\mathrm{b}$ show the comparable results using the CCDS ID catalog for analysis in both technologies. The percent detected is lower overall for the microarray data, i.e., lower within the same species but also lower across species. One can also see that the rate of cross-hybridization of human genes onto the mouse microarray chip is larger relative to the rate of crosshybridization of mouse genes onto the human microarray chip. A priori we expected that intraspecies detection (human cell line sample hybridized on a human microarray

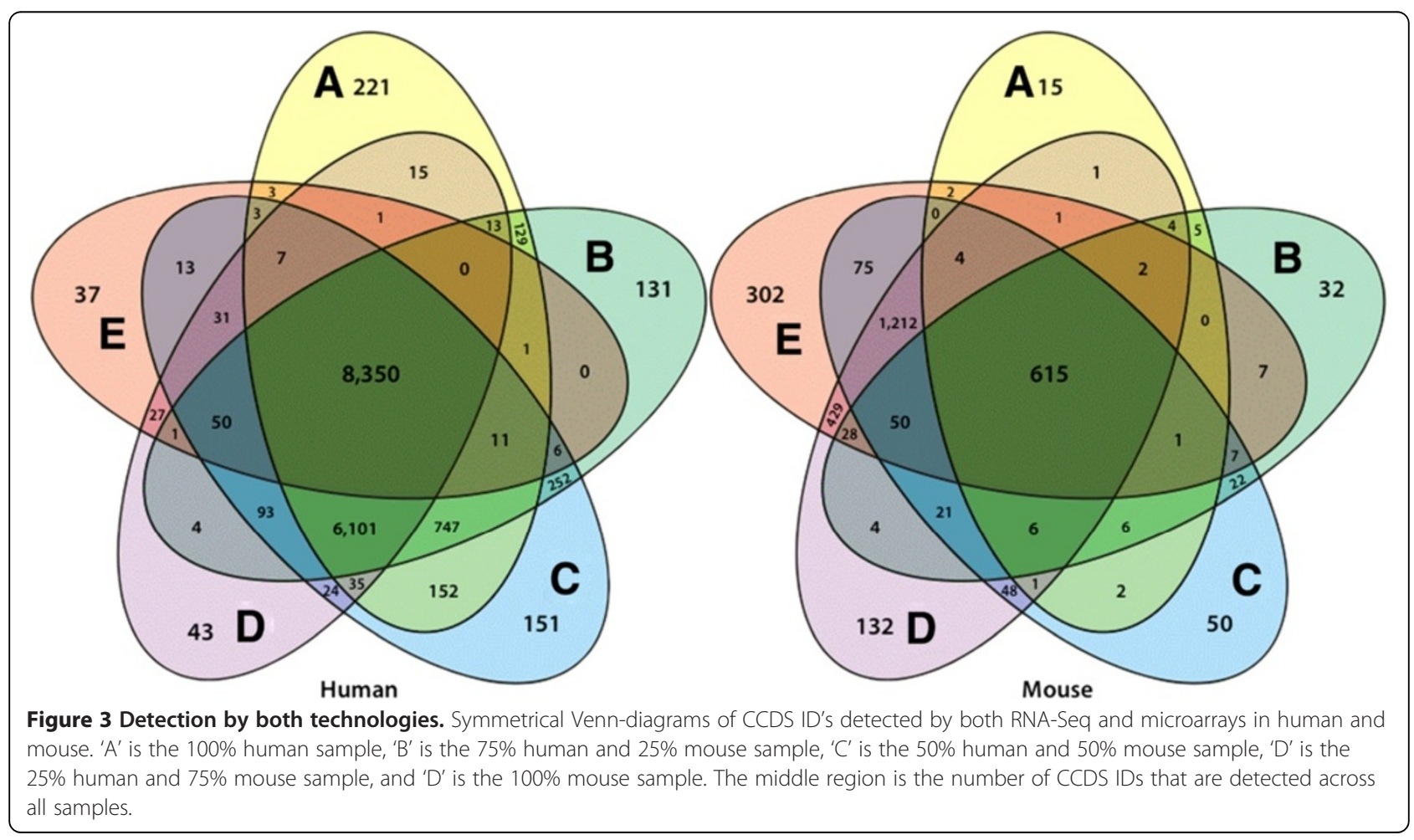




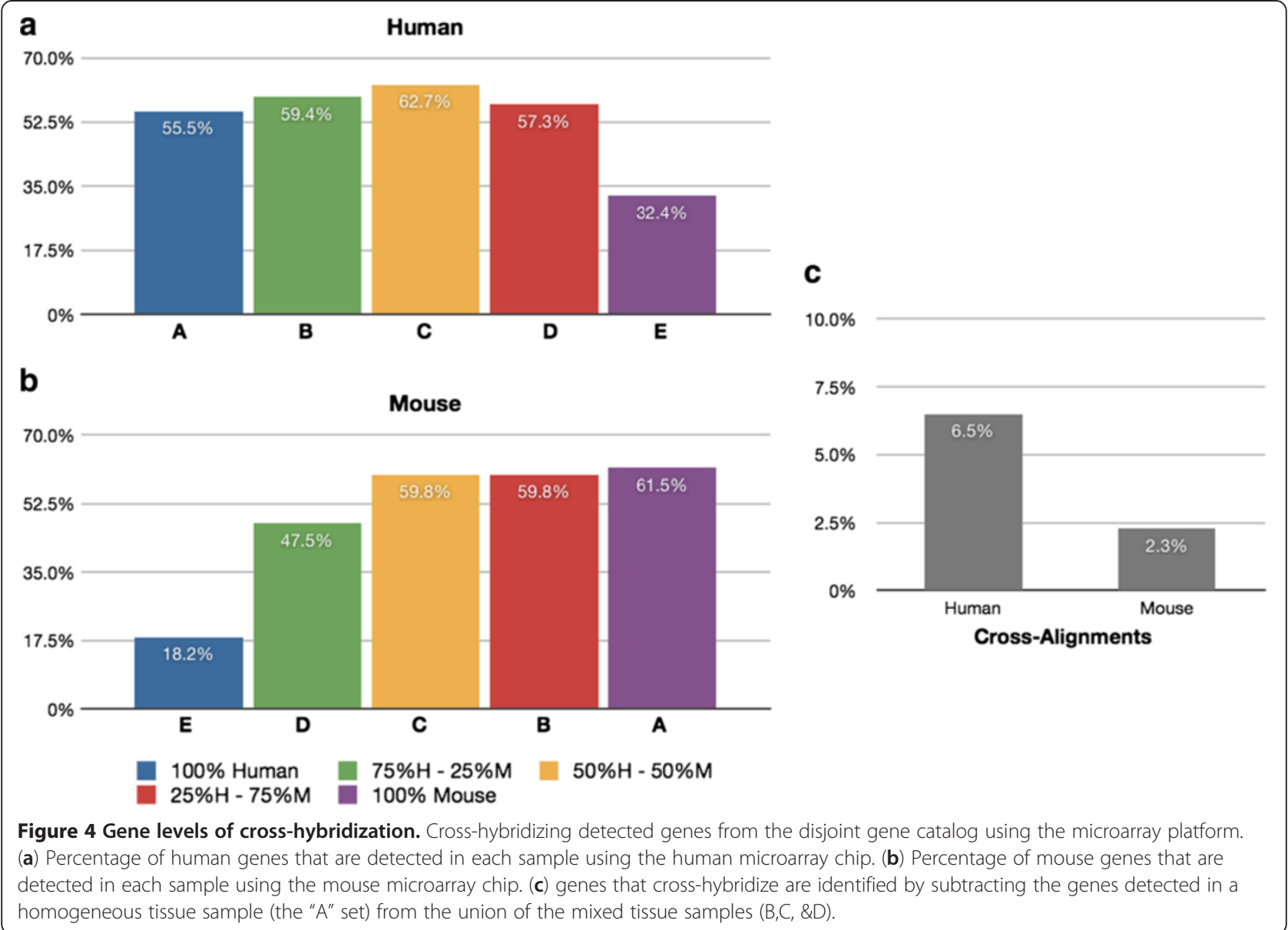

chip, or the human cell line sample RNA-Seq reads mapped onto the human reference; the mouse tissue sample hybridized on a mouse microarray chip, or mouse tissue sample RNA-Seq reads mapped onto the mouse reference) would decrease monotonically as the percentage of same-species material decreased (Additional file 1: Figures S4 and S5); however, this was not the case. In all four cases (mouse tissue on mouse chip, human cell line on human chip, mouse tissue mapped to mouse reference, human cell line mapped to human reference) only the human cell line on the human chip case shows a monotonically decreasing detection rate with decreasing human cell line percentage. For example, the detection of mouse genes by alignment to the mouse reference with the RNA-Seq data actually shows the highest level of detection in samples that are 50\%/50\% mouse/human cell line. These results may partly be explained by cross-hybridization and/or cross-alignment, i.e., if there is some cross-hybridization and/or crossalignment then it is possible that heterogeneous samples (mixtures of human and mouse) will have higher detection rates than homogeneous samples (pure mouse and human).

We considered using a much simpler but broader definition of cross-hybridization/cross-alignment. The idea is to define a human cross-hybridizer as a gene detected in a $100 \%$ human sample with a mouse microarray, and a mouse cross-hybridizer as a gene detected in a $100 \%$ mouse sample with a human microarray. The definitions from cross-alignment would be analogous. We expected that these definitions would lead to lists of genes that would be a superset of the lists we had found, because this simpler definition should identify genes either detected or undetected by same-species methods and detected by cross-species methods, while our definition only identifies genes undetected by same-species methods and detected by cross-species methods. However, we found that neither list was a proper subset of the other; for example, $45.3 \%$ (Additional file 1: Table S6) of genes we defined as human cross-aligners by our definition also appeared as a human cross-aligner by the simpler, 'pure' sample approach. Additional file 1: Tables S6-S10 contain the full overlap percentages for genes and CCDS IDs detected using both definitions.

\section{Detection by technology}

The CCDS gene catalog was employed so that we may directly compare detection by the two technologies. We 


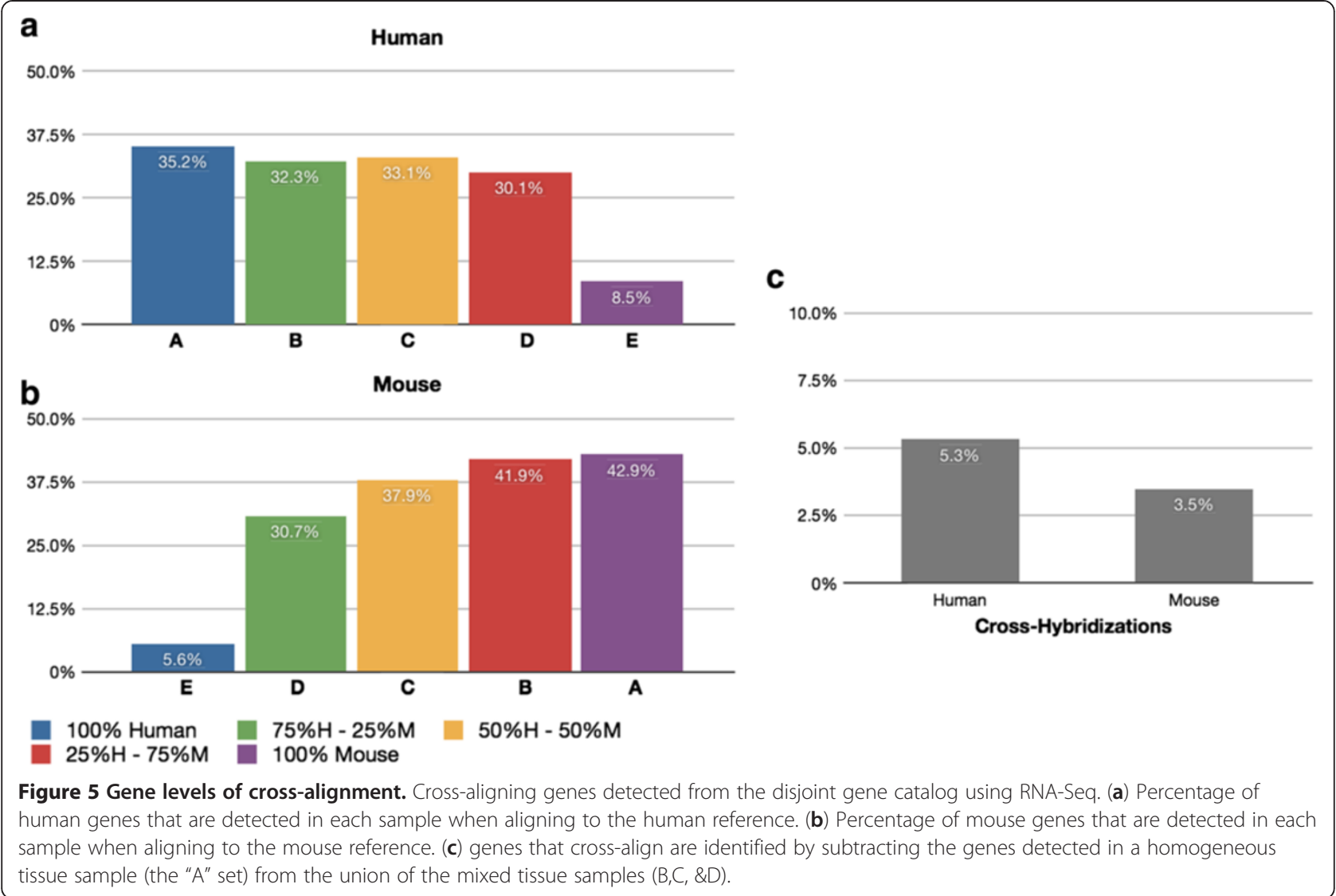

used the full set of CCDS IDs obtained from NCBI: 25,504 human CCDS IDs and 22,131 mouse CCDS IDs. It should be noted that the microarray chips only contained $65.0 \%$ of the current human CCDS IDs and $61.1 \%$ of the mouse CCDS IDs. Additional file 1: Table S2 details the levels of detection by each technology at each sample. RNA-Seq is able to detect more unique CCDS IDs by itself than the microarray chips in the heterogeneous samples: in human, RNA-Seq is able to uniquely detect, on average, about $48.8 \%$ of CCDS IDs while the microarray chips are able to uniquely detect only 4.7\%; however both technologies detect about $46.5 \%$ of the same CCDS IDs. The detected numbers are similar in mouse: RNA-Seq is able to uniquely detect $53.1 \%$ of CCDS IDs, while the microarrays are able to uniquely detect $5.4 \%$; both technologies are able to detect $41.5 \%$ of the same CCDS IDs (see Additional file 1: Figure S1).

The detection in the Homogeneous samples also follows the same pattern within a species (Venn Diagrams in Additional file 1: Figure S2): for the 100\% human sample, RNA-Seq uniquely detects $41.5 \%$ of unique human CCDS IDs, microarrays uniquely detect $7.8 \%$, and both detect $50.7 \%$ of human CCDS IDs. For the
$100 \%$ mouse sample, RNA-Seq detects $51.0 \%$ of mouse CCDS IDs, microarrays detect $3.8 \%$, and both detect $45.2 \%$ of mouse CCDS IDs. However, RNA-Seq detects a substantially greater number of CCDS IDs in the 100\% sample of the opposite species: in the $100 \%$ mouse sample, RNA-Seq is able to detect $82.7 \%$ of human CCDS IDs, while microarrays only detect $7.1 \%$ and $10.1 \%$ are detected by both. The same is true for the $100 \%$ human sample: RNA-Seq is able to detect $77.5 \%$ of mouse CCDS IDs, while microarrays are able to detect only $12.2 \%$ of mouse CCDS IDs and only $10.2 \%$ are detected by both.

For the 100\% human sample, 16,463 CCDS IDs are detected by both RNA-Seq and microarrays; of these 6,833 are uniquely detected by RNA-Seq, 8,350 are detected by both technologies, and 1,280 are uniquely detected by microarrays. For the $100 \%$ mouse sample, 15,696 mouse CCDS IDs are detected by both RNA-Seq and microarrays; of these 8,008 are uniquely detected by RNA-Seq, 7,093 are detected by both technologies, and 595 are uniquely detected by microarrays. The symmetrical Venn Diagrams $(n=5)$ in Figure 3 illustrates a detailed breakdown of the detection numbers by both technologies in each sample and for each species. 


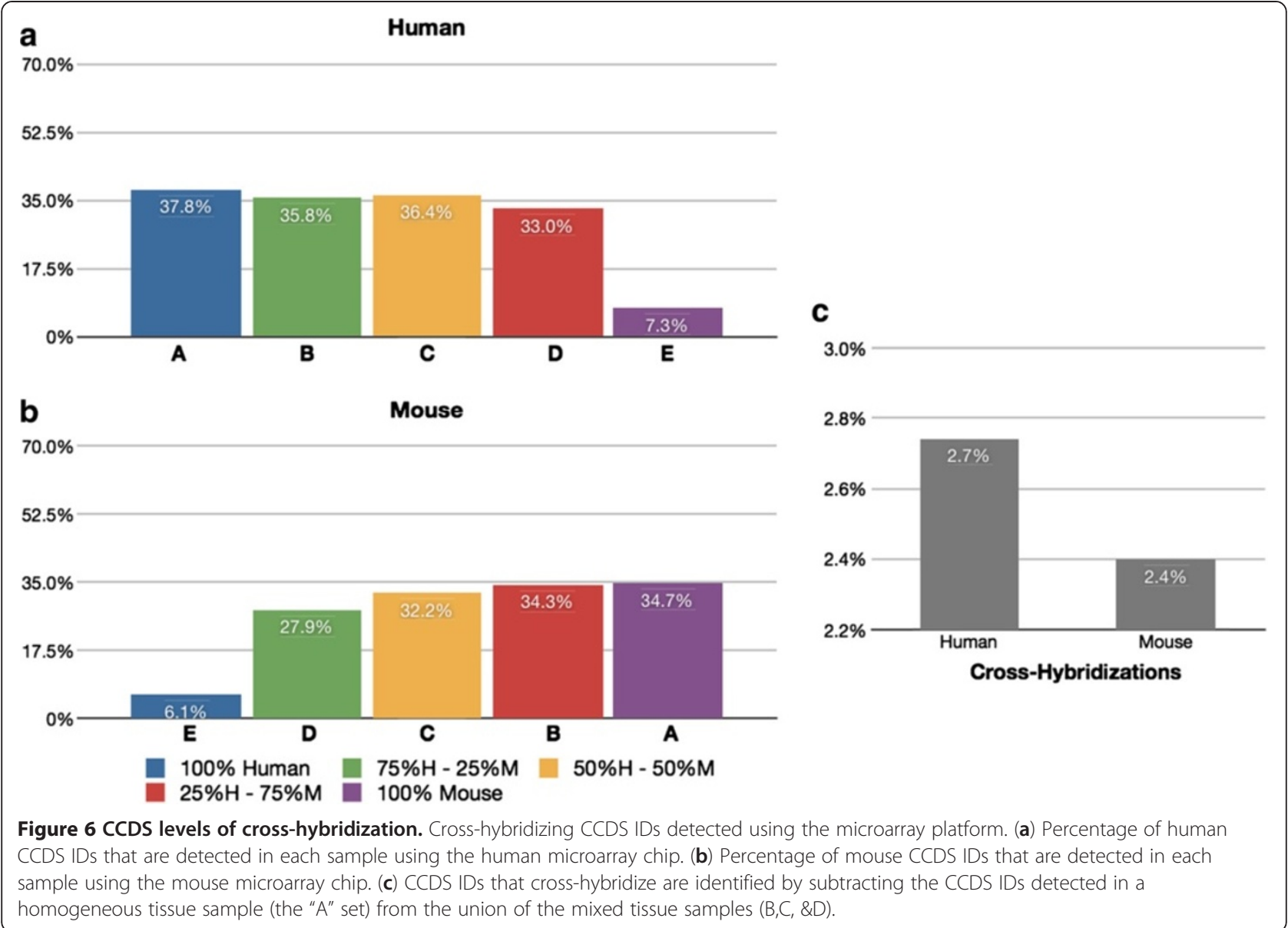

\section{Levels of cross-hybridization and cross-alignment}

Figure 4a shows the percentage of human genes from each sample that are detected on the human microarray chip, while Figure 4b shows the analogous information for mouse genes detected in the mouse microarray chip. Figure 4c displays the percentage of detected genes that represent cross-hybridization from human to mouse, and also the percentage of genes that represent crosshybridization from mouse to human. The determination of cross-hybridization is described in the Methods section. Briefly, genes that cross-hybridize from human to mouse are defined as follows. We consider all genes that are detected on the human chip in 2 of 3 independent replicates of a mixed tissue sample (any combination of mouse and human). We then subtract any genes that are detected on the human chip in 2 of 3 independent replicates of a homogeneous sample (all human). Genes that cross-hybridize from mouse to human are defined similarly. In this way we identify as cross-hybridizing all genes that are detected in mixed human \& mouse samples, but not detected in the pure human \& mouse samples.

Figure $5 \mathrm{a}$ shows the percentage of human genes that are detected using RNA-Seq in the human reference, while Figure $5 b$ shows information analogous to Figure $5 a$, but for mouse genes detected in the mouse reference. Figure $5 \mathrm{c}$ displays the percentage of detected genes that represent cross-alignment from human to mouse, and also the percentage of cross-aligning genes from mouse to human. Our definition of cross-alignment is also described in the Methods section. In brief, the crossaligning genes from human to mouse are established as follows. We consider all the genes that are detected in the human reference and transcriptome mappings, in 2 of 3 replicates of a mixed tissue sample. We then subtract any genes that are detected in the human reference and transcriptome mappings in 2 of 3 independent replicates of the homogeneous sample (all human). Cross-alignments from mouse to human are defined similarly.

The observed levels of cross-hybridization in the microarray chips in the case of a disjoint gene catalog are relatively low: $5.3 \%$ of human protein coding genes detected in the mouse sample, and $3.5 \%$ of mouse protein coding genes detected in the human samples. When we analyze the data using the normalized CCDS ID catalog (Figure 6 and Additional file 1: Figure S3) the levels of crosshybridization are also low: $2.7 \%$ of human CCDS IDs are 


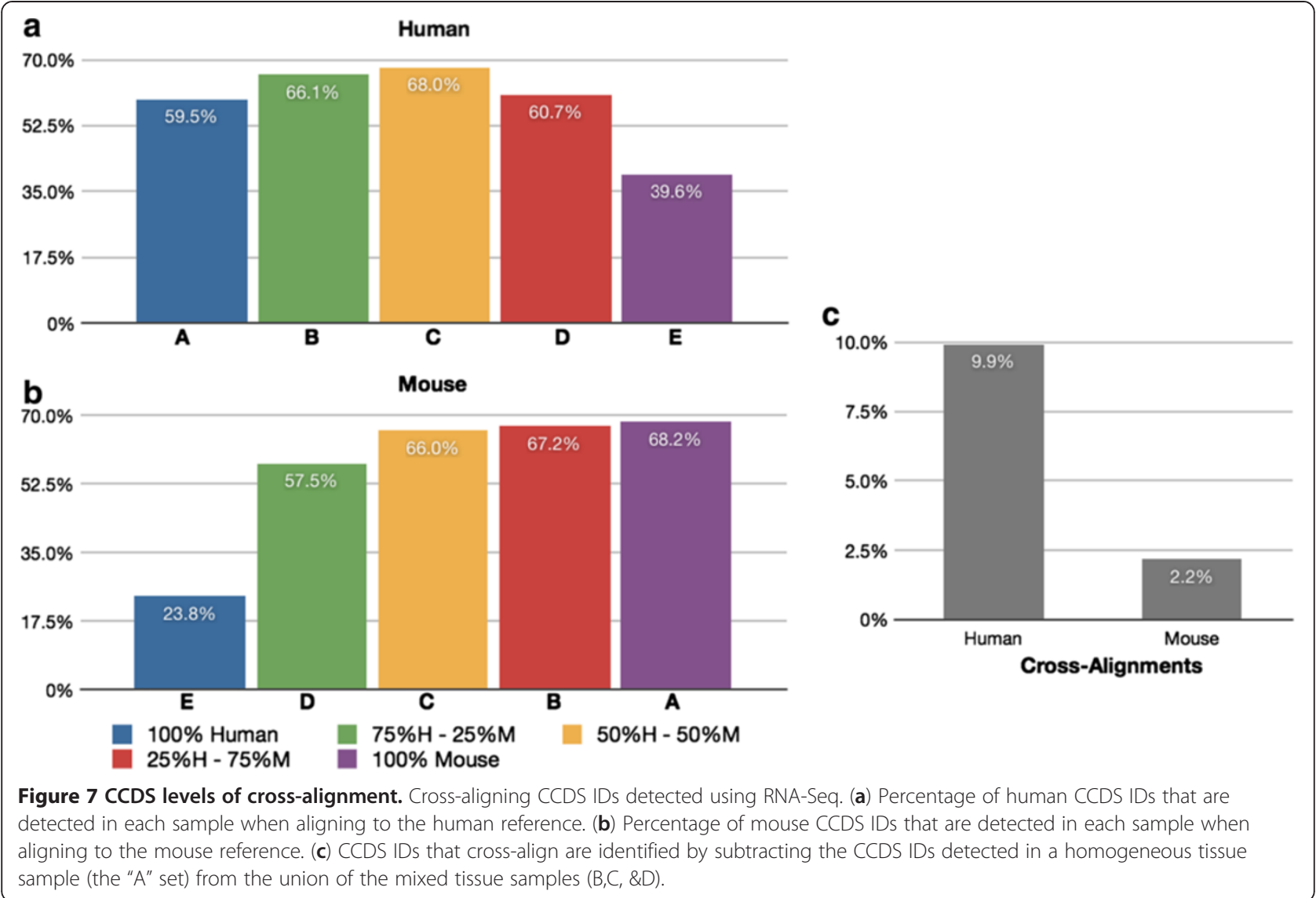

cross-hybridizing with mouse tissue, and $2.4 \%$ of detected mouse CCDS IDs are cross-hybridizing with human. This is consistent with the microarray chip manufacturer's intent to design gene probes that are species specific, i.e., the chips will detect the gene segment of interest in either mouse or human, but do not detect genes in both species. With RNA-Seq, using a disjoint gene catalog, the observed levels of cross-alignment are practically similar to the levels of cross-hybridization in the microarray chips: $6.5 \%$ of human protein coding genes are detected using the mouse reference, and $2.3 \%$ of mouse protein coding genes are detected using the human reference. Utilizing the CCDS data (Figure 7), the levels of cross-alignment are very different for the human set: $9.9 \%$ of detected human CCDS IDs are cross-aligning with mouse tissue; however, only $2.2 \%$ of detected mouse CCDS IDs are cross-aligning with human. This is in contrast to the cross-hybridizing results in which the levels were comparable for both human and mouse set. We posit that the difference is due to the gene model completeness in the mouse transcriptome relative to that of the human transcriptome [26] as well as the higher dynamic range of RNA-Seq [24]. The observed levels of cross-hybridization and crossalignment are statistically significantly different (test of proportions; $\mathrm{p}<0.05$ ), with significantly lower human cross-hybridization than cross-alignment, and significantly higher mouse cross-hybridization than crossalignment. In practical terms for all cases except human CCDS cross-alignment the percentages seem quite close and the strong statistical significance is likely due to the very large number of genes detected (i.e., very large sample sizes). Lists of cross-aligning and crosshybridizing genes for human and mouse can be found in Additional files 2 and 3 respectively.

\section{Orthologs}

We examined the number of human-mouse orthologs present in the cross-hybridizing and cross-aligning gene lists. Human-mouse ortholog data was obtained from the Mouse Genome Database (MGD; [27]). The MGD database catalogues 17,673 gene-orthologs between human and mouse. We accumulated all the cross-aligning genes from the disjoint catalog analysis and obtained 1,840 cross-aligning genes. Using these 1,840 crossaligning genes (human genes detected in the mouse tissue, and mouse genes detected in the human cell line) from the disjoint RNA-Seq results, we identified 593 human-mouse orthologs in the MGD catalog. That is, from the cross-aligning genes, 32.2\% were orthologs. For the CCDS data, we identified 16,679 mouse CCDS IDs 


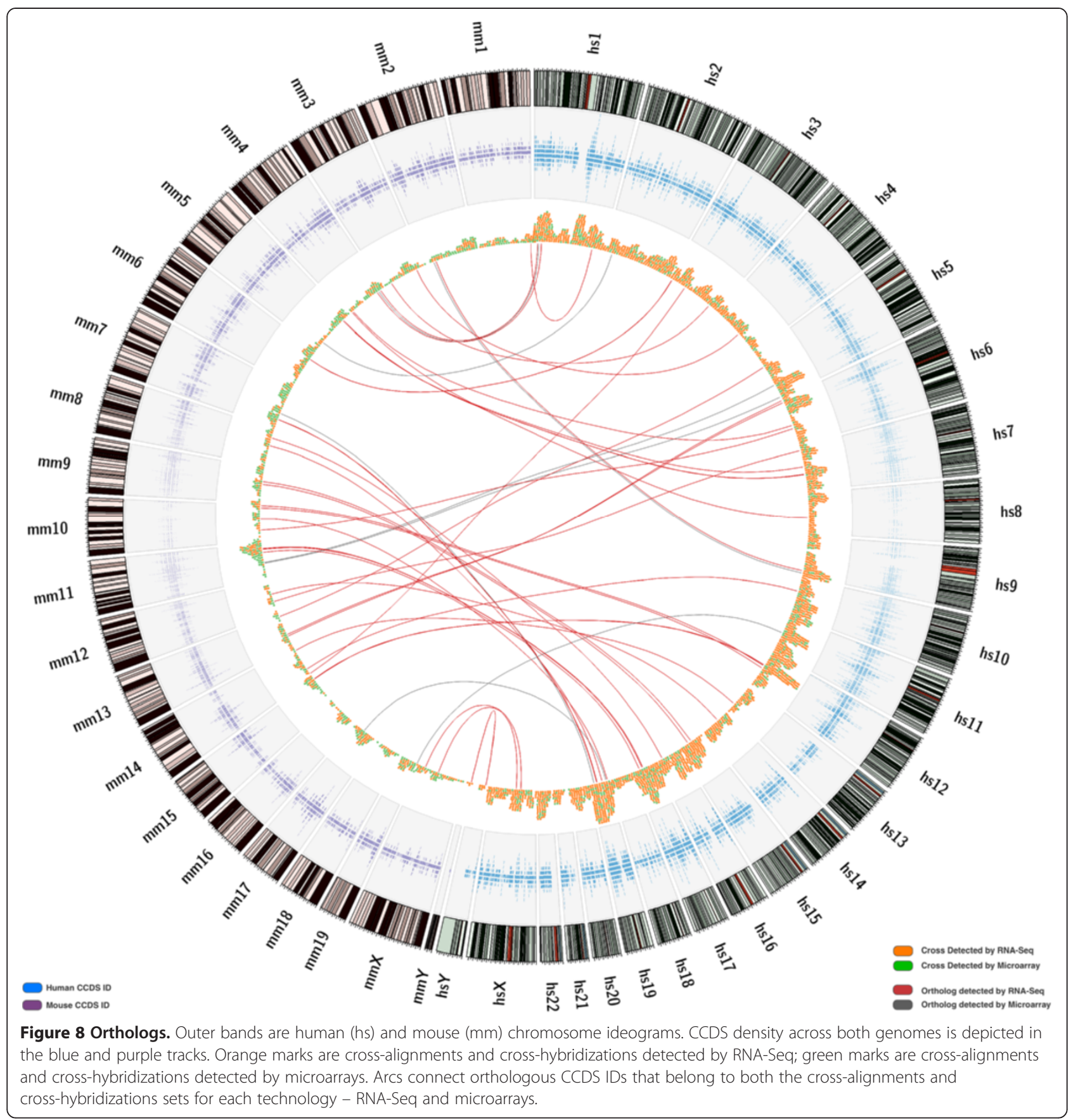

and 16,902 human CCDS IDs in the MGD database; of these, 16,292 were perfectly paired as human-mouse orthologs. Using the 2,530 cross-aligning human CCDS IDs along with the 481 cross-aligning mouse CCDS IDs, we identified 1,934 human-mouse orthologs: 1,566 CCDS IDs identified from the human cross-aligning set, and 368 identified from the mouse cross-aligning set. In total, $61.9 \%$ of the detected human cross-aligning CCDS IDs and $76.5 \%$ of the detected mouse cross-aligning CCDS IDs were human-mouse orthologs.
In the microarray analysis, we collected 4,171 crosshybridizing genes from the disjoint catalog analysis (human genes detected in the mouse tissue, and mouse genes detected in the human cell line), and identified 1,682 orthologs in the MGD catalog. That is, from the cross-hybridizing genes, $40.3 \%$ were orthologs. In the CCDS analysis, we collected 699 cross-hybridizing human CCDS IDs and 531 mouse CCDS IDs; from these, we identified 499 orthologs present in the human set, and 419 present in the mouse set. In total, $71.4 \%$ of 
the detected human cross-hybridizing CCDS IDs and $78.9 \%$ of the detected mouse cross-hybridizing CCDS IDs orthologs.

Of those orthologs found by the RNA-Seq protocol, $80.6 \%$ were detected only in human, $17.3 \%$ were detected only in mouse, and $2.1 \%$ were detected in both. For microarrays, $53.9 \%$ of the orthologs were detected only in human, $45.1 \%$ were only detected in mouse, and $1.0 \%$ was detected by both. The relatively high percent of orthologs in the detected sets helps explain why, as noted previously, we sometimes observed the highest percentage of genes detected from mixed species samples as opposed to single species samples.

Figure 8 contains a Circos [28] plot that displays the results of the normalized CCDS analysis in both the human and mouse genomes. Outer bands represent chromosome ideograms for the human genome (right) and the mouse genome (left). The blue and purple tracks showcase CCDS density for each genome and each chromosome. Levels of cross-alignment and crosshybridization are presented as orange and green marks in the third inner-most track: orange marks are those CCDS IDs identified by RNA-Seq, and green marks are those CCDS IDs identified by microarrays. The links in the middle of the diagram correspond to the humanmouse orthologs that were identified by each technology: red links represent orthologs detected by RNA-Seq and grey links represent orthologs detected by microarrays.

\section{Known cancer genes and pathways}

We examined the cross-hybridizing and cross-aligning gene lists from both the disjoint gene catalog analysis and from the CCDS analysis for genes known to play a role in cancer, or of current interest to researchers in oncology. Cross-hybridizing and cross-aligning genes in our studies include PDGF-B, b-Raf, Beta-catenin, erbB2, NF-kB, MDM2, Claudin, VEGF-R, Notch2, Cyclin B, HSP90 and Ubiquitin. These genes are of particular interest because xenografts are a common laboratory tool in oncology and there is interest in not only expression in tumors, but also in the expression in the stroma. Data from mixed samples will be insufficient for determining whether genes that cross-hybridize and cross-align are being expressed in tumor, stroma, or both. Figure 9 contains several of these genes and the platforms on which they were detected. Full lists of cross-hybridizing and cross-aligning genes are provided in the Additional file 1.

Suppose a sample of mixed tumor and stroma is arrayed on a human platform, with the intent of detecting only tumor-related genes. Genes detected in mouse tissue using human platforms could be perceived as being expressed in tumor, when in fact they are expressed in stroma or are not expressed at all. In our experiments we have found such genes. These include Angiotensin 1converting enzyme gene (ACE), which has been shown to have possible mitogenic and angiogenic effects in cell line and animal models of breast cancer [13], and heparanase

\begin{tabular}{|c|c|c|c|c|c|}
\hline \multicolumn{3}{|c|}{ Human Cross Alignment Pathways/Genes } & \multicolumn{3}{|c|}{ Human Cross Hybridization Pathways/Genes } \\
\hline Pathway & $\begin{array}{c}\text { P-Value } \\
\text { (FDR }<0.05)\end{array}$ & Genes & Pathway & $\begin{array}{c}\text { P-Value } \\
\text { (FDR<0.05) }\end{array}$ & Genes \\
\hline Regulation of EMT & $1.15 \mathrm{e}-7$ & $\begin{array}{l}\text { WNT, HGF, TGF-Beta, PDGF-B, E- } \\
\text { Cadherin, BCL2 }\end{array}$ & \multirow{2}{*}{$\begin{array}{l}\text { TGF-beta-mediated } \\
\text { Regulation of Cell } \\
\text { Proliferation }\end{array}$} & \multirow[t]{2}{*}{$1.20 \mathrm{e}-4$} & \multirow[t]{2}{*}{$\begin{array}{l}\text { PDGF-A, PDGF-B, JNK, p38 MAPK, } \\
\text { MEK6, Axin }\end{array}$} \\
\hline \multirow{2}{*}{$\begin{array}{l}\text { Cytoskeleton } \\
\text { Remodeling Keratin } \\
\text { Filaments }\end{array}$} & \multirow{2}{*}{$5.87 e-7$} & \multirow{2}{*}{$\begin{array}{l}\text { Periplakin, Tubulin alpha, Tubulin } \\
\text { beta, Keratins } 6 A / 5 / 13 / 14 / 16 / 17\end{array}$} & & & \\
\hline & & & $\begin{array}{l}\text { Signal Transduction } \\
\text { Inhibition of ERK }\end{array}$ & $1.43 e-4$ & AKT, ZAP70, JNK \\
\hline $\begin{array}{l}\text { Cell Adhesion Histamine } \\
\text { H1 Receptor Signaling }\end{array}$ & $8.24 \mathrm{e}-6$ & $\begin{array}{l}\text { GEFT, PLC-beta, MELC, Myosin II, } \\
\text { MRLC, Actininm E-cadherin, Alpha- } \\
\text { catenin }\end{array}$ & \multirow[t]{2}{*}{$\begin{array}{l}\text { TGF, WNT, and } \\
\text { Cytoskeletal Remodeling }\end{array}$} & \multirow[t]{2}{*}{$3.40 \mathrm{e}-4$} & $\begin{array}{l}\text { WNT, Frizzled, Axin, AKT, p38 MAPK, } \\
\text { MELC, MRLC, MLCK, Alpha-actinin }\end{array}$ \\
\hline $\begin{array}{l}\text { Cell Adhesion Gap } \\
\text { Junctions }\end{array}$ & $5.22 \mathrm{e}-6$ & $\begin{array}{l}\text { PKC, Actin, Occludin, Tubulin alpha, } \\
\text { Tubulin beta }\end{array}$ & & & \\
\hline \multicolumn{3}{|c|}{ Mouse Cross Alignment Pathways/Genes } & \multicolumn{3}{|c|}{ Mouse Cross Hybridization Pathways/Genes } \\
\hline Pathway & $\begin{array}{c}\text { P-Value } \\
\text { (FDR<0.05) }\end{array}$ & Genes & Pathway & $\begin{array}{l}\text { P-Value } \\
(\text { FDR<0.1) }\end{array}$ & Genes \\
\hline $\begin{array}{l}\text { Role of NEK in Cell Cycle } \\
\text { Regulation }\end{array}$ & $2.08 \mathrm{e}-4$ & $\begin{array}{l}\text { Tubulin gamma, Tubulin, Tubulin } \\
\text { alpha, HEC, Mad2a }\end{array}$ & Activin A Signaling & $1.47 \mathrm{e}-4$ & Activin A, Inhibin, BAMBI, SMURF1 \\
\hline \multirow[t]{3}{*}{ Specific Genes } & & $\begin{array}{l}\text { Rad9, WNT, Frizzled, DKK1, SMAD1, } \\
\text { EGF4, Histone H2, SMAD9 }\end{array}$ & $\begin{array}{l}\text { Role of HP1 in } \\
\text { Transcriptional Silencing }\end{array}$ & $3.41 \mathrm{e}-4$ & HDAC9, Mef2, c-Myc \\
\hline & & & $\begin{array}{l}\text { Thrombopoietin } \\
\text { Regulated Cell Processes }\end{array}$ & $6.52 \mathrm{e}-4$ & C3G, c-Cbl, GSK3, c-Myc, p27KIP1 \\
\hline & & & Specific Genes & & $\begin{array}{l}\text { Tcf (Lef), MMP28, SMURF, IL21, } \\
\text { Histone H1, Lef1 }\end{array}$ \\
\hline
\end{tabular}

Figure 9 Enriched cancer gene pathways. Pathway analysis was performed using MetaCore software from GeneGo Inc. We examined biological pathways over-represented by the genes in each human and mouse cross-hybridizing and cross-aligning CCDS lists. Distinctly different genes and biological pathways appear as cross-hybridizing \& cross-aligning depending upon the platform and tissue type. 
(HPR), which has been proposed as a target for the development of breast cancer directed gene therapy [16]. Genes from the WNT pathway also appear, such as WNT and Axin, that have been implicated as contributing to breast cancer cell proliferation [19]. Conversely, suppose a sample of mixed tumor and stroma is arrayed on a mouse platform with the intent of detecting only stromal genes. Genes detected in the human cell line using mouse platforms could be perceived as being expressed in stroma, when in fact they are expressed in tumor or not expressed at all. An example of such a gene in our experiments is $\mathrm{SHC}$ binding protein 1 (SHCBP1), which is regulated by c-Myc and the androgen receptor, and is involved in cell proliferation and growth [22]. Another such gene is Histone H1, which is implicated in breast cancer cell proliferation [30].

For the pathway analysis we used the MetaCore software (GeneGo Inc.) to examine biological pathways over-represented by the genes in each cross-hybridizing and cross-aligning list from both the disjoint catalog analysis and the CCDS analysis. This pathway analysis revealed pathways involved in TGF-beta regulation, cytoskeleton remodeling, regulation of epithelial-mesenchymal transition (EMT), DNA damage, cell adhesion, and FGFR signaling. Select pathways for both analyses are listed in Table 1 (disjoint catalog) and in Table 2 (CCDS). Full pathway results are provided in the Additional file 1.

Distinctly different genes and biological pathways appear as cross-hybridizing/cross-aligning depending upon the platform and tissue type. The cross-hybridizing human genes represent TGF-beta signaling, androgen regulation, and DNA damage, while cross-aligning human genes represent EMT, keratin filaments, and gap junctions. Similarly, cross-hybridizing mouse genes represent HP1 transcription, thrombopoetin processes, and WNT signaling, while cross-aligning mouse genes represent DNA damage, hedgehog signaling, and FGFR signaling. Figure 10 shows the top scored pathway for the cross-aligning human CCDS analysis: regulation of epithelial-mesenchymal transition (EMT) [31,32]. Regulation of EMT is of great interest to cancer researchers, particularly those interested in metastasis, as EMT is a recognized mechanism for initiating metastasis of epithelial cancer cells [33]. The EMT process may facilitate the generation of cancer cells with the mesenchymal traits needed for dissemination as well as the selfrenewal properties needed for initiation of secondary

Table 1 Enriched pathways in disjoint catalog analysis

\begin{tabular}{|c|c|c|c|c|}
\hline & \multicolumn{2}{|c|}{ Human } & \multicolumn{2}{|r|}{ Mouse } \\
\hline & Cross-alignment & Cross hybridization & Cross-alignment & Cross hybridization \\
\hline 1 & $\begin{array}{l}\text { Cytoskeleton remodeling: keratin } \\
\text { filaments }\end{array}$ & $\begin{array}{l}\text { Protein folding and maturation: } \\
\text { POMC processing }\end{array}$ & $\begin{array}{l}\text { Cytoskeleton remodeling: } \\
\text { neurofilaments }\end{array}$ & $\begin{array}{l}\text { Neurophysiological process: } \\
\text { Dopramine D2 receptor } \\
\text { transactivation of PDGFR in CNS }\end{array}$ \\
\hline 2 & Signal transduction: CAMP signaling & $\begin{array}{c}\text { Normal and pathological: TGF- } \\
\text { beta mediated regulation of cell } \\
\text { proliferation }\end{array}$ & $\begin{array}{l}\text { DNA damage: ATM/ATR } \\
\text { regulation of G } 2 \mathrm{M} \text { checkpoint }\end{array}$ & $\begin{array}{c}\text { Transcription role of heterochromatin } \\
\text { protein } 1 \text { (HP1) family in } \\
\text { transcriptional silencing }\end{array}$ \\
\hline 3 & $\begin{array}{l}\text { Development: regulation of epithelial } \\
\text { to mesenchymal transition (EMT) }\end{array}$ & $\begin{array}{c}\text { Cytoskeleton remodeling: TGF, } \\
\text { WNT and cytoskeletal } \\
\text { remodeling }\end{array}$ & $\begin{array}{l}\text { Cell cycle: role of Nek in cell } \\
\text { cycle regulation }\end{array}$ & $\begin{array}{c}\text { Development: hedgehog and PTH } \\
\text { signaling pathways in bone and } \\
\text { cartilage development }\end{array}$ \\
\hline 4 & Cell adhesion: gap junctions & $\begin{array}{l}\text { Signal transduction, Erk } \\
\text { interaction: inhibition of Erk }\end{array}$ & $\begin{array}{l}\text { Cell cycle: spindle assembly } \\
\text { and chromosome separation }\end{array}$ & $\begin{array}{l}\text { Cytoskeleton remodeling: } \\
\text { neurofilaments }\end{array}$ \\
\hline 5 & $\begin{array}{l}\text { Development: transcription regulation } \\
\text { of granulocyte development }\end{array}$ & $\begin{array}{l}\text { Development: melanocyte } \\
\text { development ang pigmentation }\end{array}$ & $\begin{array}{l}\text { Development: hedgehog } \\
\text { signaling }\end{array}$ & $\begin{array}{l}\text { Development: Gastrin in } \\
\text { differentiation of the gastric mucosa }\end{array}$ \\
\hline 6 & $\begin{array}{l}\text { Cytoskeleton remodelling: regulation } \\
\text { of actin cytoskeleton by Rho GTPases }\end{array}$ & $\begin{array}{l}\text { Translation: non-genomic } \\
\text { (rapid) action of androgen } \\
\text { receptor }\end{array}$ & $\begin{array}{c}\text { Mechanisms of CFTR } \\
\text { activation by S- } \\
\text { nitrosoglutathione (normal } \\
\text { and CF) }\end{array}$ & Blood coagulation: Blood coagulation \\
\hline 7 & $\begin{array}{c}\text { Cell adhesion: Histamine } \mathrm{H} 1 \text { receptor } \\
\text { signlaing in the interruption to cell } \\
\text { barrier integrity }\end{array}$ & $\begin{array}{l}\text { G-protein signaling : Rap1A } \\
\text { regulation pathway }\end{array}$ & $\begin{array}{c}\text { Development: FGFR signaling } \\
\text { pathway }\end{array}$ & $\begin{array}{l}\text { Development thrombopotein- } \\
\text { regulated cell processes }\end{array}$ \\
\hline 8 & $\begin{array}{l}\text { Development: beta-adrenergic } \\
\text { receptors signaling via CAMP }\end{array}$ & $\begin{array}{c}\text { Development: GDNF family } \\
\text { signaling }\end{array}$ & $\begin{array}{c}\text { Muscle contraction: regulation } \\
\text { of eNOS activity in endothelial } \\
\text { cells }\end{array}$ & $\begin{array}{l}\text { Neurophysiologiacal process: ACM } \\
\text { regulation of nerve impulse }\end{array}$ \\
\hline 9 & $\begin{array}{c}\text { Cytoskeleton remodeling: reverse } \\
\text { signaling by Ephrin B }\end{array}$ & $\begin{array}{l}\text { DNA damage: role of SUMO in } \\
\text { p53 regulation }\end{array}$ & $\begin{array}{l}\text { GFTR folding and maturation } \\
\text { (normal and CF) }\end{array}$ & Development: WNT5 signaling \\
\hline 10 & $\begin{array}{l}\text { Regulation of lipid metabolism: } \\
\text { regualtion of lipid metabolism by } \\
\text { niacin and isoprenaline }\end{array}$ & $\begin{array}{l}\text { Muscle contaction: relaxin } \\
\text { signaling pathway }\end{array}$ & $\begin{array}{l}\text { DNA damage: role of SUMO in } \\
\text { p53 regulation }\end{array}$ & $\begin{array}{l}\text { Transport: Alpha-2 energenic receptor } \\
\text { regulation of Ion channels }\end{array}$ \\
\hline
\end{tabular}


Table 2 Enriched pathways in CCDS analysis

\begin{tabular}{|c|c|c|c|c|}
\hline & \multicolumn{2}{|c|}{ Human } & \multicolumn{2}{|r|}{ Mouse } \\
\hline & Cross-alignment & Cross hybridization & Cross-alignment & Cross hybridization \\
\hline 1 & $\begin{array}{l}\text { Development: regulation of } \\
\text { epithelial to mesenchymal (EMT) }\end{array}$ & $\begin{array}{l}\text { Protein folding and maturation: } \\
\text { POMC processing }\end{array}$ & $\begin{array}{l}\text { Cell cycle: role of Nek in } \\
\text { cell cycle regulation }\end{array}$ & $\begin{array}{c}\text { Signal transduction: activin A signaling } \\
\text { regulation }\end{array}$ \\
\hline 2 & $\begin{array}{l}\text { Cytoskeleton remodeling: Keratin } \\
\text { filaments }\end{array}$ & $\begin{array}{l}\text { Normal and pathological TGF- } \\
\text { beta mediated regulation of cell } \\
\text { proliferation }\end{array}$ & $\begin{array}{l}\text { Cell cycle: the } \\
\text { methaphase checkpoint }\end{array}$ & $\begin{array}{c}\text { Transcription role of heterochromatin } \\
\text { protein } 1 \text { (HP1) family in trancriptional } \\
\text { silencing }\end{array}$ \\
\hline 3 & $\begin{array}{c}\text { Cardia hypertrophy NF-AT signaling } \\
\text { in cardia hypertrophy }\end{array}$ & $\begin{array}{l}\text { Signal transduction, Erk } \\
\text { interactions: inhibition of Erk }\end{array}$ & $\begin{array}{l}\text { Cytoskeleton } \\
\text { remodeling: } \\
\text { neurofilaments }\end{array}$ & Cytoskeleton remodeling: neurofilaments \\
\hline 4 & Cell adhesion: gap junctions & $\begin{array}{l}\text { Development: melaconyte } \\
\text { development and pigmentation }\end{array}$ & ATP metabolism & $\begin{array}{c}\text { Dvelopment: thrombopoietin regulated cell } \\
\text { process }\end{array}$ \\
\hline 5 & $\begin{array}{l}\text { Cell adhesion: hestamine } \mathrm{H} 1 \\
\text { receptor signaling in the interruption } \\
\text { of cell barrier integrity }\end{array}$ & $\begin{array}{l}\text { Cytoskeleton remodeling: TGF, } \\
\text { WNT and cytoskeletal remodeling }\end{array}$ & $\begin{array}{l}\text { Cell cycle: spindle } \\
\text { assembly and } \\
\text { chromosome } \\
\text { separation }\end{array}$ & $\begin{array}{l}\text { Neurophysiological process nNOS signaling } \\
\text { in neronal synapases }\end{array}$ \\
\hline 6 & Signal transduction: CAMP signaling & $\begin{array}{c}\text { Develeopment A2A receptor } \\
\text { signaling }\end{array}$ & dCTP/dUTP metabolism & $\begin{array}{l}\text { Development: role of HDAC and calcium/ } \\
\text { calmodulin dependent kinase (CaMK) in } \\
\text { control of skeletal of myogenesis }\end{array}$ \\
\hline 7 & $\begin{array}{l}\text { Immune response: MIF- } \\
\text { neuroendocrine macrophage } \\
\text { connector }\end{array}$ & $\begin{array}{l}\text { Development transcription } \\
\text { regulation of granulocyte } \\
\text { development }\end{array}$ & $\begin{array}{c}\text { Apoptosis and survival: } \\
\text { DNA damage induced } \\
\text { apoptosis }\end{array}$ & $\begin{array}{c}\text { Protein folding: membrane trafficking and } \\
\text { signal transduction of G-alpha heterotrimeic } \\
\text { G-protein }\end{array}$ \\
\hline 8 & $\begin{array}{l}\text { Development transcription: } \\
\text { regulation of grabulocyte } \\
\text { development }\end{array}$ & $\begin{array}{c}\text { Cytoskeleton remodeling Alpha- } \\
1 \mathrm{~A} \text { andrenergic recepto- } \\
\text { dependent inhibition of PI3K }\end{array}$ & $\begin{array}{l}\text { Transcription: androgen } \\
\text { receptor nuclear } \\
\text { signaling }\end{array}$ & $\begin{array}{l}\text { Development: role of activin A in cell } \\
\text { differentiation and proliferation }\end{array}$ \\
\hline 9 & $\begin{array}{l}\text { Cell adhesion: edothelial cell } \\
\text { contacts by junctional mechanisms }\end{array}$ & $\begin{array}{l}\text { Muscle contraction: relaxin } \\
\text { signaling pathway }\end{array}$ & $\begin{array}{l}\text { Neurophysiological } \\
\text { process: ACM } \\
\text { regulation of nerve } \\
\text { impulse }\end{array}$ & Development: WNT5A signaling \\
\hline 10 & $\begin{array}{l}\text { Atherosclerosis: role of ZNF202 in } \\
\text { regulation of expression of genes } \\
\text { involved in Atherosclerosis }\end{array}$ & $\begin{array}{l}\text { Immune response: lectin induced } \\
\text { complement pathway }\end{array}$ & $\begin{array}{l}\text { Development WNT } \\
\text { signaling pathway }\end{array}$ & $\begin{array}{c}\text { Development: PIP3 signaling in cardiac } \\
\text { myocytes }\end{array}$ \\
\hline
\end{tabular}

Enriched GeneGo pathway maps for human and mouse. Gene lists for pathway analysis were obtained from the CCDS ID analysis for cross-hybridization (microarrays) and cross-alignment (RNA-Seq).

tumors. There is accumulating evidence that EMT and mesenchymal-related gene expression are associated with aggressive breast cancer subtypes and poor clinical outcome [34]. Many of the genes from our lists that appear in this and other pathways, have been implicated in tumor-stromal interactions and/or are related to stromal responses to invasion. These include PGDF [35], MMP2 [36], Tubulins [37], and the WNT signaling pathway [38]. We also computed the overlap of our human and mouse gene lists against the curated gene set in the MSigDB [39] gene set repository (Additional file 1: Tables S10-S13). This analysis identified signatures from multiple biological processes with relevance to cancer research including drug targets, chromosome maintenance, cellular proliferation, and therapeutic response.

\section{Discussion}

When a mixed sample is analyzed using platforms specific to one species, it is possible that tissue from the other species will be detected, contaminating the assessment of which genes are present, or their levels of expression [40]. This is confirmed by our results demonstrating that although the overall levels of crosshybridization and cross-alignment may be low, the specific genes that are affected are relevant to cancer research. Our cross-hybridization/cross-alignment lists contain a few thousand genes, some of which are known to play roles in biological processes related to cancer. Affected processes include EMT, Wnt signaling, DNA damage, and TGF-beta signaling.

The lists of affected genes and processes vary by species and platform. This is relevant to researchers in making decisions about how to process samples (LCM or no LCM?) and what tools to use to measure expression (microarray or NGS?). It is clear that such decisions are influenced not only by time and cost, but also by their impact on expression measurements. We have examined one context relevant to oncologic research, i.e., breast cancer pseudoxenografts, and we surmise that examinations of other contexts will prove valuable to the research community. 


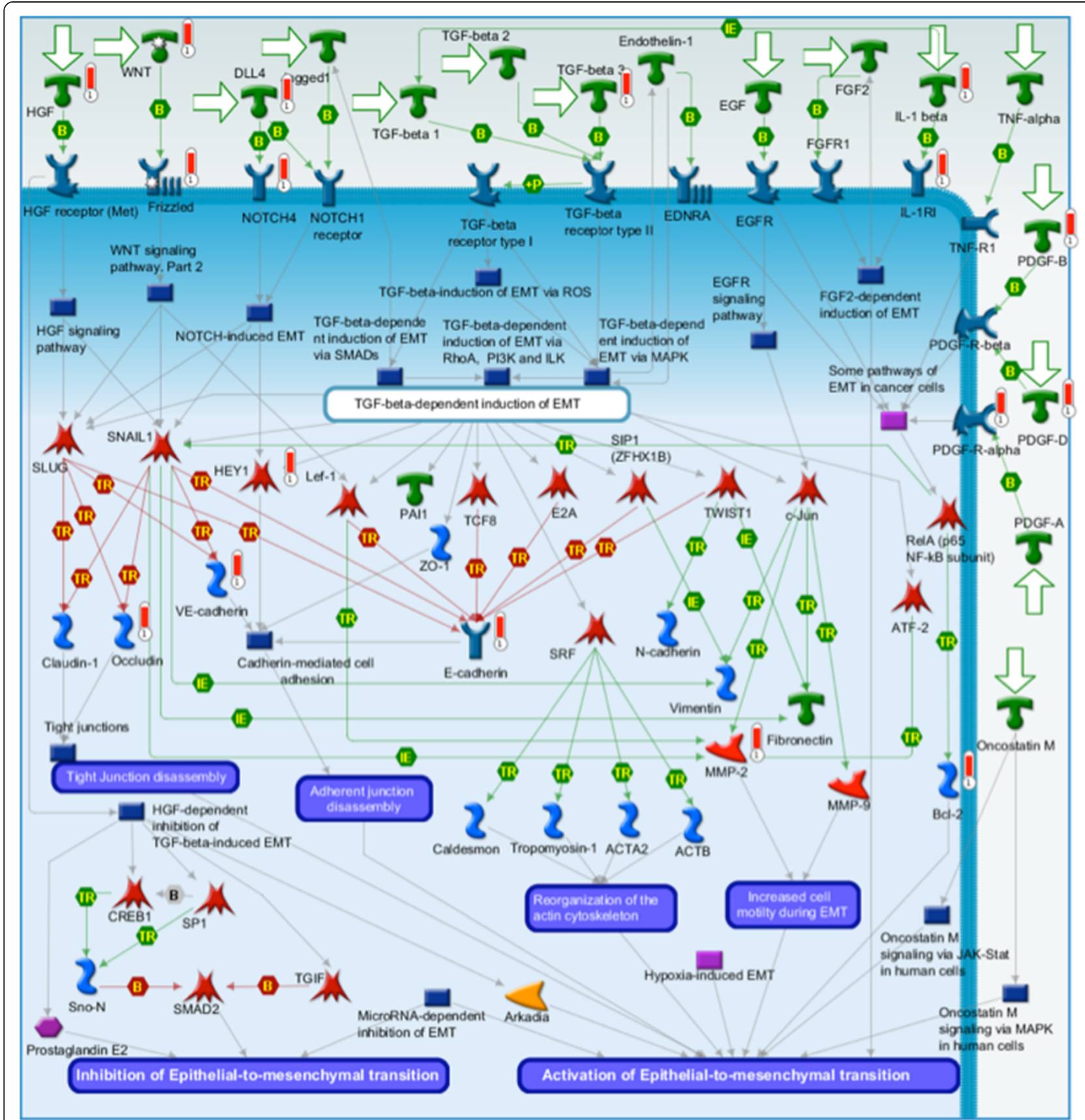

Figure 10 EMT Pathway. The top scored GeneGO pathway map (lowest p-value) for the human cross-aligning CCDS set is a development pathway: regulation of epithelial to mesenchymal transition (EMT). Upward thermometers with a red color are up-regulated genes, and downward blue thermometers indicated down-regulated genes.

\section{Conclusions}

Oncology studies involving xenografts can be very useful in identifying genomic changes in both stroma and tumor that accompany the onset of disease and metastatic growth. Due to the small size of xenografts from metastatic tumors, and the expense of LCM, investigators who are interested in changes specific to stroma, or specific to tumor, may choose to select a gross sample (a mixture of stroma and tumor) and use a genomic platform that is specific to one species, either mouse or human.

The concern in this context is cross-hybridization (for microarrays) or cross-alignment (for RNA-Seq). Our results, using a definition of cross-hybridization/crossalignment which should only identify genes with undetectable expression in same-species platforms but detectable expression in cross-species platforms - indicate 
that the overall percentage of genes affected by crosshybridization and cross-alignment is small for both platforms. However, this percentage does include genes that are of interest to oncologic researchers, as they have known or purported roles in cancer progression and metastasis. The specific genes that cross-hybridize/crossalign are specific to the platform used to detect expression. As such the question of which platform to use with mixed tissues from xenografts - microarrays or highthroughput RNA sequencing - appears to be primarily a question of cost and the specific genes of research interest.

\section{Accession code}

NCBI Gene Expression Omnibus: Microarray and RNASeq data has been deposited with accession number GSE40892.

\section{Additional files}

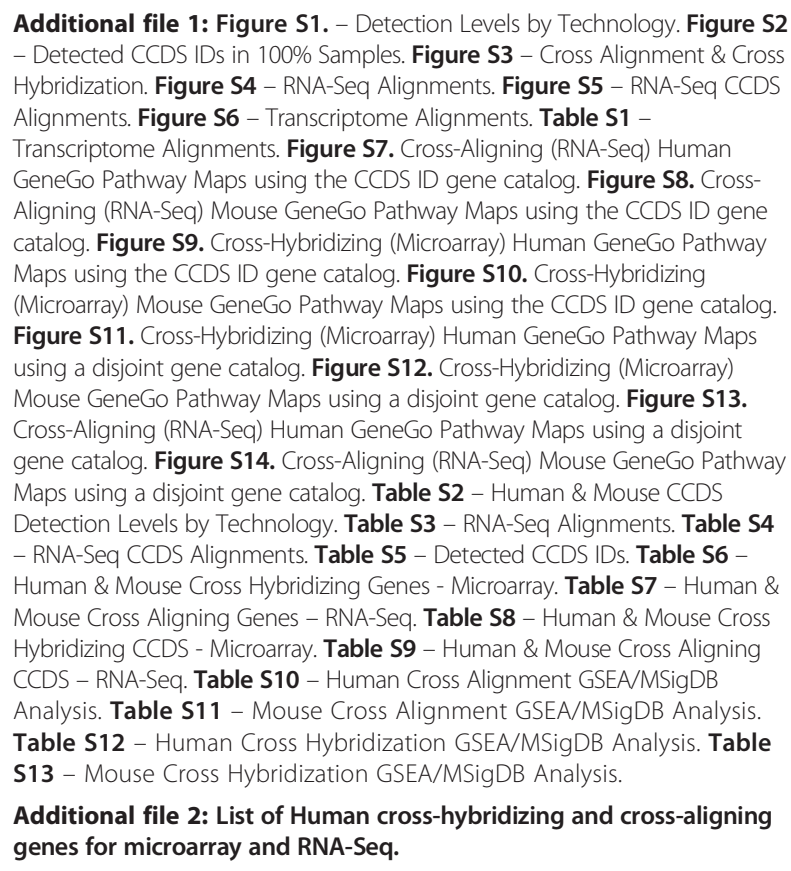

Additional file 2: List of Human cross-hybridizing and cross-aligning genes for microarray and RNA-Seq.

Additional file 3: List of Mouse cross-hybridizing and cross-aligning genes found in microarrays and RNA-Seq.

\section{Competing interests}

The authors declare that they have no competing interests.

\section{Authors' contributions}

CV carried out the bioinformatic analyses and helped draft the manuscript. PS helped design the study, carried out the biological experiments, and provided the expression data. NT helped design the study and guide the bioinformatic analyses. JC coordinated the study, guided the bioinformatic analyses, and participated in manuscript drafting. All authors read and approved the final manuscript.

\section{Acknowledgements}

This work was substantially supported by grant number 7K25CA111636 from the National Cancer Institute to JC

\section{Author details}

'Center for Computational Science, University of Miami, Miami, FL, USA. ${ }^{2}$ Department of Medicine, University of Miami, Miami, FL, USA. ${ }^{3}$ Division of Biostatistics, Department of Epidemiology and Public Health, University of Miami, Miami, FL, USA. ${ }^{4}$ Department of Computer Science, University of Miami, Miami, FL, USA

Received: 25 October 2012 Accepted: 18 March 2013

Published: 18 April 2013

\section{References}

1. Cloonan N, Forrest ARR, Kolle G, Gardiner BBA, Faulkner GJ, Brown MK, Taylor DF, Steptoe AL, Wani S, Bethel G, Robertson AJ, Perkins AC, Bruce SJ, Lee CC, Ranade SS, Peckham HE, Manning JM, McKernan KJ, Grimmond SM: Stem cell transcriptome profiling via massive-scale mRNA sequencing. Nat Methods 2008, 5:613-619.

2. Marioni JC, Mason CE, Mane SM, Stephens M, Gilad Y: RNA-seq: an assessment of technical reproducibility and comparison with gene expression arrays. Genome Res 2008, 18:1509-1517.

3. TIsty TD, Coussens LM: Tumor stroma and requlation of cancer development. http://dx.doi.org/10.1146/annurev.pathol.1.110304.100224.

4. Mortazavi A, Williams BA, McCue K, Schaeffer L, Wold B: Mapping and quantifying mammalian transcriptomes by RNA-Seq. Nat Methods 2008, 5:621-628.

5. Hu M, Polyak K: Microenvironmental regulation of cancer development. Curr Opin Genet Dev 2008, 18:27-34.

6. Sultan M, Schulz MH, Richard H, Magen A, Klingenhoff A, Scherf M, Seifert M, Borodina T, Soldatov A, Parkhomchuk D, Schmidt D, O'Keeffe S, Haas S, Vingron M, Lehrach H, Yaspo M-L: A global view of gene activity and alternative splicing by deep sequencing of the human transcriptome. Science 2008, 321:956-960

7. Arendt L, Rudnick J, Keller P: Stroma in breast development and disease. Seminars in cell \& ... 2010.

8. Schena M, Shalon D, Davis RW, Brown PO: Quantitative monitoring of gene expression patterns with a complementary DNA microarray. Science 1995, 270:467-470

9. Cleator SJ, Powles TJ, Dexter T, Fulford L, Mackay A, Smith IE, Valgeirsson H, Ashworth A, Dowsett M: The effect of the stromal component of breast tumours on prediction of clinical outcome using gene expression microarray analysis. Breast Cancer Res 2006, 8:R32

10. Flicek P, Amode MR, Barrell D, Beal K, Brent S, Carvalho-Silva D, Clapham P, Coates G, Fairley S, Fitzgerald S, Gil L, Gordon L, Hendrix M, Hourlier T, Johnson N, Kähäri AK, Keefe D, Keenan S, Kinsella R, Komorowska M, Koscielny G, Kulesha E, Larsson P, Longden I, McLaren W, Muffato M, Overduin B, Pignatelli M, Pritchard B, Riat HS, et al: Ensembl 2012. Nucleic Acids Res 2012, 40:D84-90.

11. Wang M, Master SR, Chodosh LA: Computational expression deconvolution in a complex mammalian organ. BMC Bioinformatics 2006 7:328

12. Trapnell C, Salzberg SL: How to map billions of short reads onto genomes. Nat Biotechnol 2009, 27:455-457.

13. Koh W-P, Yuan J-M, Sun C-L, van den Berg D, Seow A, Lee H-P, Yu MC: Angiotensin I-converting enzyme (ACE) gene polymorphism and breast cancer risk among Chinese women in Singapore. Cancer Res 2003, 63:573-578.

14. Trapnell C, Pachter L, Salzberg SL: TopHat: discovering splice junctions with RNA-Seq. Bioinformatics 2009, 25:1105-1111.

15. Morton CL, Houghton PJ: Establishment of human tumor xenografts in immunodeficient mice. Nat Protoc 2007, 2:247-250.

16. Breidenbach M, Rein DT, Schöndorf T, Khan KN, Herrmann I, Schmidt T, Reynolds PN, Vlodavsky I, Haviv YS, Curiel DT: A new targeting approach for breast cancer gene therapy using the heparanase promoter. Cancer Lett 2006, 240:114-122.

17. Fend $\mathrm{F}$, Raffeld $\mathrm{M}$ : Laser capture microdissection in pathology. J Clin Pathol 2000, 53:666-672.

18. Kent WJ, Sugnet CW, Furey TS, Roskin KM, Pringle TH, Zahler AM, Haussler D: The human genome browser at UCSC. Genome Res 2002, 12:996-1006. 
19. Schlange T, Matsuda Y, Lienhard S, Huber A, Hynes NE: Autocrine WNT signaling contributes to breast cancer cell proliferation via the canonical WNT pathway and EGFR transactivation. Breast Cancer Res 2007, 9:R63.

20. Gosink MM, Petrie HT, Tsinoremas NF: Electronically subtracting expression patterns from a mixed cell population. Bioinformatics 2007, 23:3328-3334

21. Tarazona S, García-Alcalde F, Dopazo J, Ferrer A, Conesa A: Differential expression in RNA-seq: a matter of depth. Genome Res 2011, 21:2213-2223.

22. Schmandt R, Liu SK, McGlade CJ: Cloning and characterization of mPAL, a novel Shc SH2 domain-binding protein expressed in proliferating cells. Oncogene 1999, 18:1867-1879.

23. Zhao Y, Simon R: Gene expression deconvolution in clinical samples. Genome Med 2010, 2:93.

24. Wang Z, Gerstein M, Snyder M: RNA-Seq: a revolutionary tool for transcriptomics. Nat Rev Genet 2009, 10:57-63.

25. Li H, Durbin R: Fast and accurate long-read alignment with BurrowsWheeler transform. Bioinformatics 2010, 26:589-595.

26. Trapnell C, Williams BA, Pertea G, Mortazavi A, Kwan G, van Baren MJ, Salzberg SL, Wold BJ, Pachter L: Transcript assembly and quantification by RNA-Seq reveals unannotated transcripts and isoform switching during cell differentiation. Nat Biotechnol 2010, 28:511-515.

27. Blake JA, Richardson JE, Bult CJ, Kadin JA, Eppig JT, Mouse Genome Database Group: MGD: the Mouse Genome Database. Nucleic Acids Res 2003, 31:193-195.

28. Krzywinski M, Schein J, Birol I, Connors J, Gascoyne R, Horsman D, Jones SJ, Marra MA: Circos: an information aesthetic for comparative genomics. Genome Res 2009, 19:1639-1645.

29. Pruitt KD, Harrow J, Harte RA, Wallin C, Diekhans M, Maglott DR, Searle $S$, Farrell CM, Loveland JE, Ruef BJ, Hart E, Suner M-M, Landrum MJ, Aken B, Ayling S, Baertsch R, Fernandez-Banet J, Cherry JL, Curwen V, Dicuccio M, Kellis M, Lee J, Lin MF, Schuster M, Shkeda A, Amid C, Brown G, Dukhanina $\mathrm{O}$, Frankish A, Hart J, et al: The consensus coding sequence (CCDS) project: Identifying a common protein-coding gene set for the human and mouse genomes. Genome Res 2009, 19:1316-1323.

30. Vani G, Vanisree AJ, Shyamaladevi CS: Histone $\mathrm{H} 1$ inhibits the proliferation of MCF 7 and MDA MB 231 human breast cancer cells. Cell Biol Int 2006, 30:326-331.

31. Kalluri R, Weinberg RA: The basics of epithelial-mesenchymal transition. J Clin Invest 2009, 119:1420-1428.

32. Hollier BG, Evans $K$, Mani SA: The epithelial-to-mesenchymal transition and cancer stem cells: a coalition against cancer therapies. J Mammary Gland Biol Neoplasia 2009, 14:29-43.

33. Garber K: Epithelial-to-mesenchymal transition is important to metastasis, but questions remain. J Natl Cancer Inst 2008, 100:232-3-239.

34. Sethi S, Sarkar FH, Ahmed Q, Bandyopadhyay S, Nahleh ZA, Semaan A, Sakr W, Munkarah A, Ali-Fehmi R: Molecular markers of epithelial-to-mesenchymal transition are associated with tumor aggressiveness in breast carcinoma. Transl Oncol 2011, 4:222-226.

35. Bianchini G, Qi Y, Alvarez RH, Iwamoto T, Coutant C, Ibrahim NK, Valero V, Cristofanilli M, Green MC, Radvanyi L, Hatzis C, Hortobagyi GN, Andre F, Gianni L, Symmans WF, Pusztai L: Molecular anatomy of breast cancer stroma and its prognostic value in estrogen receptor-positive and -negative cancers. J Clin Oncol 2010, 28:4316-4323.

36. Bacac M, Provero P, Mayran N, Stehle J-C, Fusco C, Stamenkovic I: A mouse stromal response to tumor invasion predicts prostate and breast cancer patient survival. PLOS ONE 2006, 1:e32.

37. Dozier JH, Hiser L, Davis JA, Thomas NS, Tucci MA, Benghuzzi HA Frankfurter A, Correia JJ, Lobert S: Beta class II tubulin predominates in normal and tumor breast tissues. Breast Cancer Res 2003, 5:R157-R169.

38. Finak G, Bertos N, Pepin F, Sadekova S, Souleimanova M, Zhao H, Chen H, Omeroglu G, Meterissian S, Omeroglu A, Hallett M, Park M: Stromal gene expression predicts clinical outcome in breast cancer. Nat Med 2008 14:518-527.
39. Liberzon A, Subramanian A, Pinchback R, Thorvaldsdóttir H, Tamayo P, Mesirov JP: Molecular signatures database (MSigDB) 3.0. Bioinformatics 2011, 27:1739-1740

40. Iorns E, Clarke J, Ward T, Dean S, Lippman M: Simultaneous analysis of tumor and stromal gene expression profiles from xenograft models. Breast Cancer Res Treat 2012, 131:321-324.

doi:10.1186/2043-9113-3-8

Cite this article as: Valdes et al.: Characteristics of cross-hybridization and cross-alignment of expression in pseudo-xenograft samples by RNA-Seq and microarrays. Journal of Clinical Bioinformatics 2013 3:8.

\section{Submit your next manuscript to BioMed Central and take full advantage of:}

- Convenient online submission

- Thorough peer review

- No space constraints or color figure charges

- Immediate publication on acceptance

- Inclusion in PubMed, CAS, Scopus and Google Scholar

- Research which is freely available for redistribution

Submit your manuscript at www.biomedcentral.com/submit
Biomed Central 